\title{
Early Signaling by Vascular Endothelial Growth Factor and Placental Growth Factor in Human Bone Marrow-Derived Endothelial Cells Is Mediated by Superoxide
}

\author{
Manya Dhar-Mascareno ${ }^{a}$ Eduardo Mascareno ${ }^{b}$ David W. Golde ${ }^{c, \dagger}$ \\ ${ }^{a}$ Department of Biological Sciences, SUNY College at Old Westbury, Old Westbury, N.Y., ${ }^{b}$ Department of \\ Anatomy and Cell Biology, State University of New York, Downstate Medical Center, and ' ${ }^{\mathrm{D}}$ Department of Medicine, \\ Memorial Sloan-Kettering Cancer Center, New York, N.Y., USA
}

\section{Key Words}

Endothelium - Reactive oxygen species - Placental growth factor $\cdot$ Vascular endothelial growth factor $\cdot$ Superoxide dismutase $\cdot$ Receptor phosphorylation $\cdot$ Angiogenesis

\begin{abstract}
Aims: We investigated the role of superoxide $\mathrm{O}_{2}^{-}$during the initiation of vascular endothelial growth factor (VEGF)- and placental growth factor (PIGF)-mediated signal transduction in bone marrow-derived endothelial cells. Methods: BMhTERT cells were treated with VEGF or PIGF in the presence or absence of antioxidants. The signaling pathways downstream were analyzed by immunoprecipitation and Western blotting. Superoxide and reactive oxygen species (ROS) were measured using Superluminol or 2',7'-dichlorofluorescein fluorescence measurements. Results: We show here that VEGF and PIGF generate extracellular and intracellular $\mathrm{O}_{2}^{-}$that regulates their downstream signaling transduction pathways. Indeed, the extracellular $\mathrm{O}_{2}^{-}$generated treatment of endothelial cells (using hypoxanthine/xanthine oxidase) was sufficient to initiate receptor phosphorylation of VEGF receptor 2. The PIGF treatment of endothelial cells increased the generation of intracellular ROS in an extracellular $\mathrm{O}_{2}^{-}$dependent manner. Quenching of intracellular ROS by resveratrol inhibits PIGF- and VEGF-dependent induction of MAP kinase phosphorylation. Additionally, we found that
\end{abstract}

\section{KARGER}

() 2009 S. Karger AG, Base

Fax +41613061234 E-Mail karger@karger.ch www.karger.com www.karger.com/jvr the interaction of VEGF and PIGF with their specific receptors generates $\mathrm{O}_{2}^{-}$in a cell-free system. Endothelial cells treated with VEGF stop proliferation in the presence of extracellular catalase, superoxide dismutase or peroxiredoxin IV. Conclusion: Our studies underscore the role of $\mathrm{O}_{2}^{-}$as a critical regulator of VEGF and PIGF signal transduction initiation in endothelial cells.

Copyright $\odot 2009$ S. Karger AG, Basel

\section{Introduction}

The vascular endothelial growth factor (VEGF) gene family currently includes 6 members: VEGF-A, placental growth factor (PlGF), VEGF-B, VEGF-C, VEGF-D and VEGF-E [1]. Three receptors with tyrosine kinase activities have been identified as VEGF receptors: VEGFR-1 (Flt-1) and VEGFR-2 (KDR/Flk-1) [2] with apparent molecular weights of 180 and $230 \mathrm{kDa}$, respectively, and VEGFR-3 [3]. In addition to VEGF, PlGF has also emerged as an important proangiogenic factor. Unlike VEGF-A which binds both VEGFR-1 and VEGFR-2, PIGF specifically binds VEGFR-1. Studies of PlGF-deficient mice have shown that PlGF is required for pathologic angiogenesis, including retinal and choroidal neovascularization [4].

Reactive oxygen species (ROS), like $\mathrm{H}_{2} \mathrm{O}_{2}$, superoxide $\left(\mathrm{O}_{2}^{-}\right)$and the hydroxyl radical, have been identified as es-

Dr. Manya Dhar-Mascaren

Department of Biological Sciences

SUNY College at Old Westbury

223 Store Hill Rd, Old Westbury, NY 11568 (USA)

Tel. +1 516876 2737, Fax +1 516876 2704, E-Mail mascarenom@oldwestbury.edu 
sential mediators that regulate the transduction of signals from the membrane to the nucleus via oxidation and reduction in proteins $[5,6]$. ROS are produced by vascular cells following stimulation with growth factors including epidermal growth factor, granulocyte macrophage colony-stimulating factor (GM-CSF) and platelet-derived growth factor $[7,8]$. While NADPH oxidase is the primary source of $\mathrm{O}_{2}^{-}$in endothelial cells $[9,10]$, we investigate whether other sources contribute to the formation of $\mathrm{O}_{2}^{-}$.

Our previous work showed that GM-CSF receptor $\alpha$ subunit, lacking the cytoplasmic domain, was able to signal in an extracellular $\mathrm{H}_{2} \mathrm{O}_{2}$-dependent manner [11] and that GM-CSF interaction with its ligand leads to the generation of $\mathrm{H}_{2} \mathrm{O}_{2}$ extracellularly [12]. In this study, we investigated the role of extracellular ROS in the initiation of signal transduction mediated by VEGF and PlGF. We identified that VEGF induced VEGFR phosphorylation and its downstream signaling pathways are dependent on extracellular superoxide, and that VEGF-VEGFR binding generates $\mathrm{O}_{2}^{-}$. We propose that extracellular $\mathrm{O}_{2}^{-}$formed by the VEGF-VEGFR-1 and PlGF-VEGFR-1 interaction is critical for the maintenance of the signaling transduction pathways and transcriptional events observed during angiogenesis.

\section{Materials and Methods}

Materials used include: anti-VEGFR-2 and VEGFR-1 polyclonal antibody (Santa Cruz); phosphotyrosine antibody 4G10, A/G Plus-Agarose (R\&D Systems, Minneapolis, Minn., USA); anti-phospho p44/42-MAP kinase and anti-p44/42 MAP kinase (Upstate); Western blotting detection system (Amersham Biosciences, Piscataway, N.J., USA); phospho-AKT (Ser473), phosphoAKT (Thr308) and AKT (Cell Signaling Technologies, Inc.); Superluminol Assay Kit (World Precision Instruments); and CellTiter-Glo ${ }^{\circledR}$ reagent (Promega). Human VEGFR and VEGFR-1 cDNA were a gift from Dr. L.C. Walsh (University of Upsala, Upasla, Sweden).

\section{Cell Culture}

The BMhTERT cell line was cultured in EBM2 medium with growth factor supplement (Clonetics). 293T (human kidney epithelial) cells were grown in DMEM-high glucose supplemented with $10 \%$ heat-inactivated FBS, $1 \%$ L-glutamine and $1 \%$ penicillin/streptomycin. cAMP responsive element (CRE)-dependent signaling was performed using $293 \mathrm{~T}$ cells, which were transiently transfected with VEGFR-2 cDNA, CRE-luciferase reporter plasmid (Clontech), by Superfect (Stratagene). SV40-Renilla luciferase cotransfection was included as a control. Cells were washed twice with PBS, lysed in passive lysis buffer, and luciferase activity was analyzed using the dual luciferase reporter system (Promega). Luciferase activity was normalized relative to the SV40-Renilla control.

\section{Immunoprecipitations}

Cultured cells were starved in serum-free medium for $16 \mathrm{~h}$. Cells were washed with PBS and suspended and lysed in cell lysis buffer containing $150 \mathrm{mM} \mathrm{NaCl}, 2.5 \mathrm{mM} \mathrm{MgCl}_{2}, 0.05 \mathrm{mM}$ EDTA, $50 \mathrm{mM}$ HEPES (pH 7.4), 0.5\% Triton, 10\% glycerol and protease inhibitors (Boehringer Mannheim). Total cell lysates were clarified by centrifugation at $10,000 \mathrm{~g}$ for $10 \mathrm{~min}$. Total cell lysate was incubated overnight with anti-receptor antibody for VEGFR-1 and VEGFR-2 and recovered by incubation with protein $\mathrm{A} / \mathrm{G}$ Plus-Agarose for $2 \mathrm{~h}$ at $4{ }^{\circ} \mathrm{C}$. The proteins were eluted by boiling and analyzed by SDS polyacrylamide gel electrophoresis followed by immunoblotting. Hypoxanthine $(125 \mu \mathrm{M} /$ xanthine oxidase $0.75 \mathrm{mU} / \mathrm{ml}$ ) for $1 \mathrm{~min}$ was used as source of superoxide.

\section{Superoxide Measurements}

Superoxide was detected using Superluminol (WPI). Superluminol $(40 \mu \mathrm{l})$ and $20 \mu \mathrm{l}$ of WPI enhancer were mixed followed by the addition of $200 \mathrm{nM}$ receptor or $1 \mu \mathrm{M}$ cognate ligand or a combination of the 2 in the presence of $50 \mathrm{U} / \mathrm{ml}$ superoxide dismutase (SOD). Superoxide production was measured by luminescence counts for 5-10 measurements with an integration time of 5-15 s using the Lumat LB9501 luminometer. The background luminescence was determined by mixing Superluminol and enhancer in buffer without proteins.

\section{Measurement of Intracellular ROS}

BMhTERT cells were plated at subconfluence on 96-well dishes. Twenty-four hours later, the media were replaced with serumfree media and the cells cultured for $16 \mathrm{~h}$. The cells were washed with PBS, $20 \mu \mathrm{g} / \mathrm{ml} 2^{\prime}, 7^{\prime}$-dichlorofluorescein (DCF) diacetate was added for $20 \mathrm{~min}$ and washed and then stimulated with $50 \mathrm{ng} / \mathrm{ml}$ PlGF in the presence or absence of SOD $100 \mathrm{U} / \mathrm{ml}$. DCF fluorescence was measured every minute.

\section{Cell Proliferation Assay}

Cells with seeded in a 96-well plate with 5,000 cells per well. Cells were then made quiescent for $16 \mathrm{~h}$ and treated with VEGF in the presence or absence of catalase, SOD or peroxiredoxin IV (PRDXIV) for $24 \mathrm{~h}$, after which an equal volume of CellTiter-Glo reagent was added to each well of cell culture medium, and the luminescence is read with an integration time set for 0.25 to $1 \mathrm{~s}$.

Statistical Analysis

Statistical significance was set at $\mathrm{p}<0.005$. One-way ANOVA was performed for statistical comparisons followed by Bonferroni posttests.

\section{Results}

\section{Superoxide Induces the Tyrosine Phosphorylation of} VEGFR-1 and VEGFR-2 in BMhTERT Cells

It has been described that extracellular treatment of endothelial cells by catalase inhibits VEGF-induced cell signaling [13]. Catalase is a tetrameric protein of $240 \mathrm{kDa}$, and hence, an extracellular antioxidant and cell impermeable [14]. The results showed that in the endothelial cell line BMhTERT [15], VEGF triggered the phosphory- 
Fig. 1. Ligand-dependent receptor phosphorylation is attenuated by extracellular SOD and catalase (CAT). ${ }^{*} \mathrm{p}<0.05$ indicates statistical significance, using oneway ANOVA followed by Bonferroni's multiple comparison test. a Quiescent BMhTERT cells were stimulated with 20 $\mathrm{ng} / \mathrm{ml}$ of VEGF for $2 \mathrm{~min}$. Cell lysates were subjected to immunoprecipitation with anti-VEGFR-1 antibody followed by Western blotting with phosphotyrosine antibody (4G10). Loading of the receptor was detected by Western blotting with VEGFR1 antibody. Catalase (100 and 1,000 U/ml) and SOD (100 and $500 \mathrm{U} / \mathrm{ml}$ ) were added to the cells immediately before VEGF treatment. b Tyrosine phosphorylation of VEGFR-2 in BMhTERT cells stimulated with $20 \mathrm{ng} / \mathrm{ml}$ of VEGF was detected by immunoprecipitation with anti-VEGFR-2 antibody followed by phosphotyrosine antibody (4G10). Catalase (100 and 1,000 U/ $\mathrm{ml})$ and SOD (100 and $500 \mathrm{U} / \mathrm{ml})$ were added to the cells immediately before VEGF treatment. Each experiment was performed in triplicate, and a representative figure is shown. The histograms represent the values of the ratio between the phosphorylated protein and the total protein.
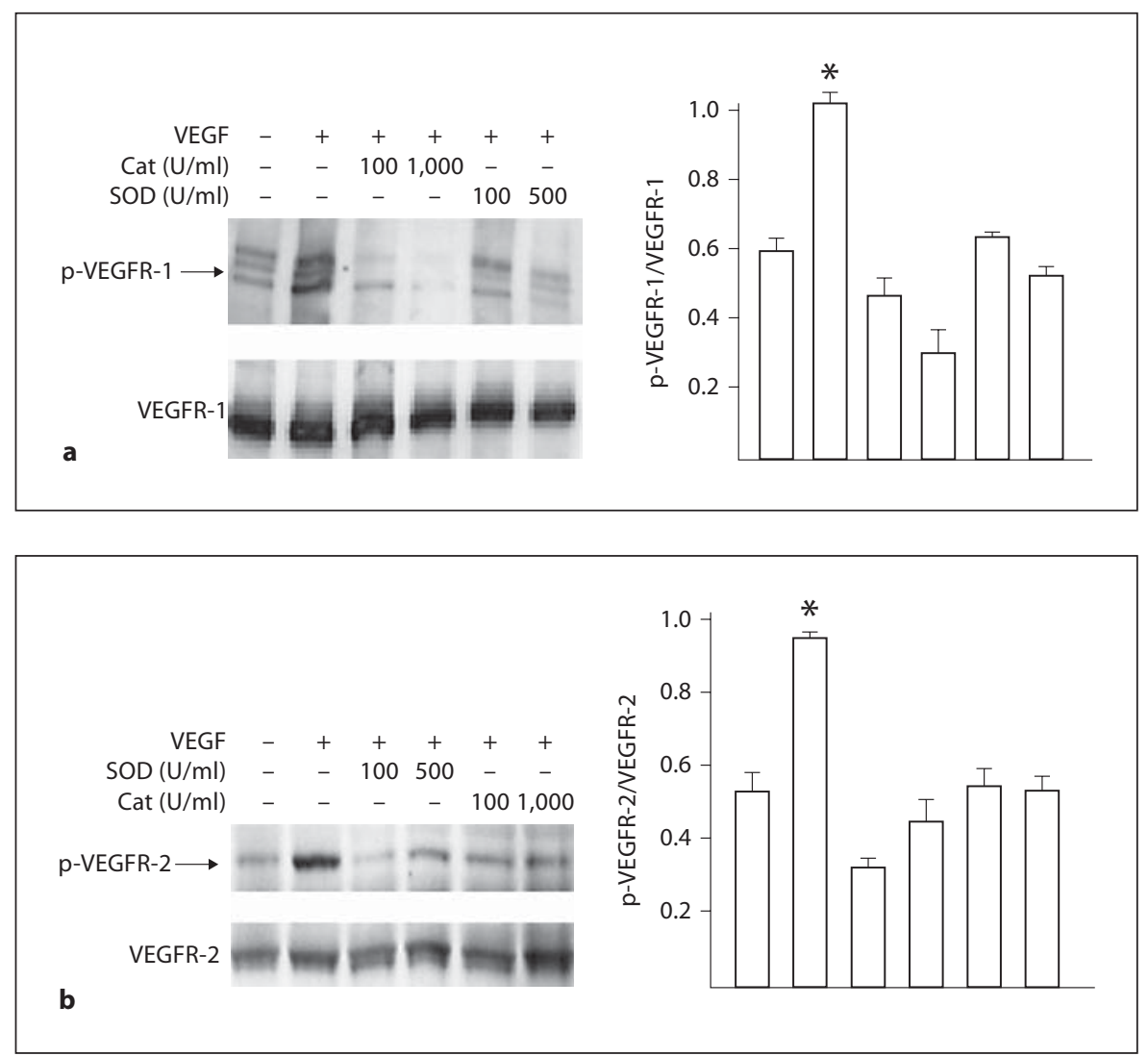

lation of VEGFR-1 and VEGFR-2 that was attenuated by extracellular catalase and SOD (fig. 1).

Although it is known that $\mathrm{H}_{2} \mathrm{O}_{2}$ enhances phosphorylation of VEGFRs [13], we hypothesize that the $\mathrm{O}_{2}^{-}$species itself could induce the phosphorylation of VEGFR-2. As shown in figure $2 \mathrm{a}$, treatment with extracellular superoxide induced tyrosine phosphorylation of VEGFR-2, and it was inhibited by SOD. In contrast, PlGF did not induce phosphorylation of VEGFR-2.

Having demonstrated that VEGFR phosphorylation can be initiated by extracellular $\mathrm{O}_{2}^{-}$alone, we investigated the effect of extracellular SOD during VEGF-dependent transcription. Transcription gene targets of VEGF-mediated signaling include genes containing CRE in their promoters [16]. Transiently transfected 293T cells with a CRE-luciferase reporter vector were treated with VEGF and the reporter activity determined in the presence or absence of SOD. VEGF treatment triggered a $50 \%$ increase in CRE-luciferase activity; however, extracellular SOD blocked the reporter activity (fig. 2b).

We further evaluated the regulation of cell proliferation in response to the ROS present outside the cell.
BMhTERT cells were grown in 96-well plates and treated with VEGF in the presence or absence of catalase or SOD and the cell proliferation was assessed. To ensure continuous expression of the antioxidant in the extracellular medium, PRDXIV cDNA was transfected in BMhTERT cells, and the proliferation of transfected cells was compared with that of untransfected cells. The presence of PRDXIV in the conditioned medium was ascertained by Western blotting (data not shown). As shown in figure 2c, VEGF-dependent cell proliferation was completely stopped in the presence of extracellular antioxidants. These results complement studies showing inhibition of endothelial proliferation by antioxidants, although in most studies, intracellular scavengers of ROS have been used $[17,18]$.

\section{Extracellular $\mathrm{O}_{2}^{-}$Regulates Signaling Events Mediated by $\mathrm{PlGF}$}

We investigated the nature of ROS involved in perpetuating the signaling axis inside the cell using specific cell-permeable antioxidant-like resveratrol, a quencher of hydroxyl and $\mathrm{O}_{2}^{-}$species. The results show that phosphor- 

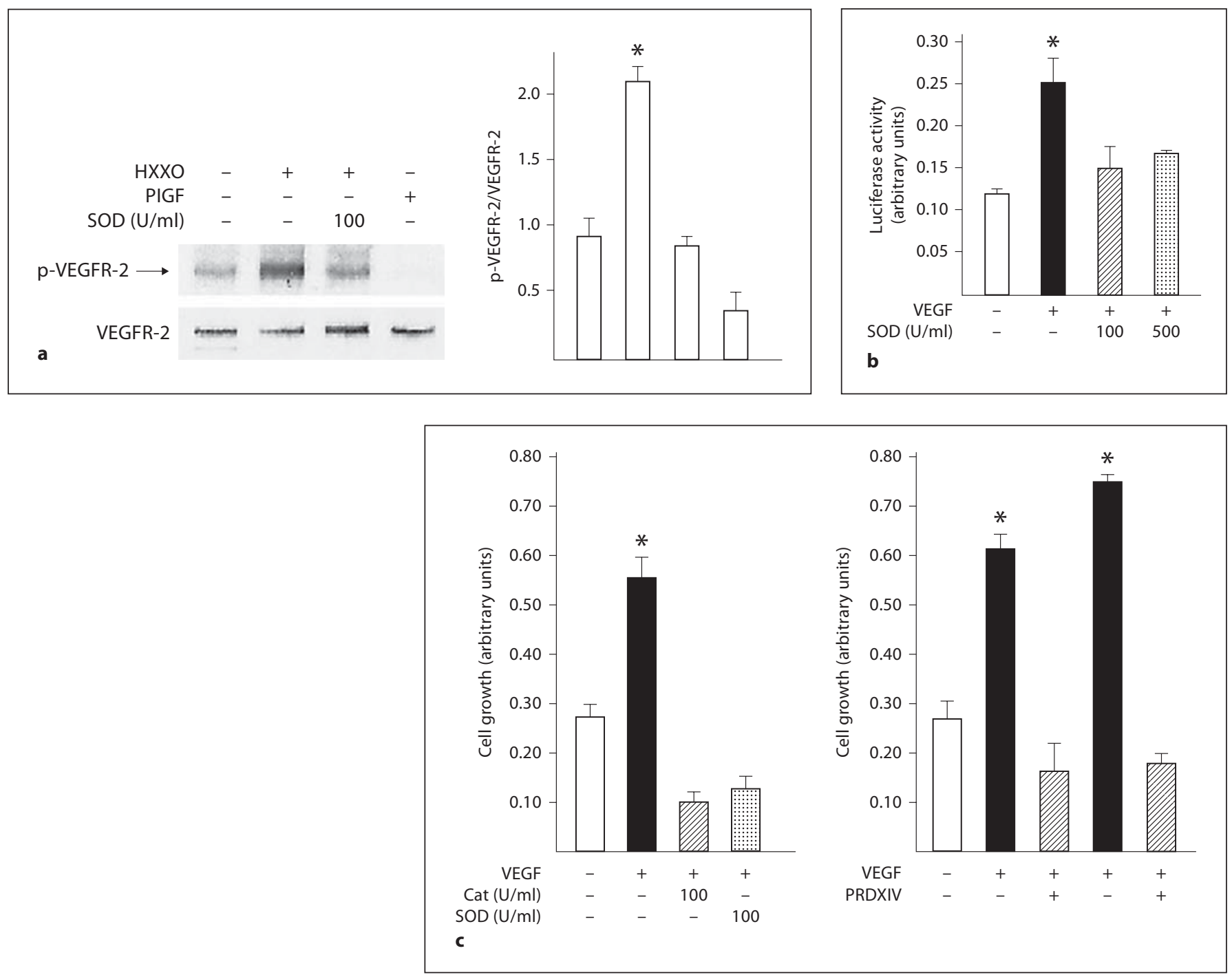

Fig. 2. Superoxide-induced VEGFR-2 phosphorylation. * $\mathrm{p}<0.05$ indicates statistical significance, using one-way ANOVA followed by Bonferroni's multiple comparison test. a BMhTERT cells were exposed to HXXO mixture or $20 \mathrm{ng} / \mathrm{ml} \mathrm{PlGF}$ for $1 \mathrm{~min}$. Cell lysates were immunoprecipitated with anti-VEGFR-2 antibody and then analyzed by Western blot using phosphotyrosine antibody. SOD was added just prior to the addition of HXXO. The histogram represents the values of the ratio between the phosphorylated protein and the total protein. $\mathbf{b}$ Luciferase activity of 293T cells transfected with VEGFR-2 and CRE-luciferase construct, incubated for $5 \mathrm{~h}$ with $20 \mathrm{ng} / \mathrm{ml}$ VEGF, with or without SOD (100 and $500 \mathrm{U} / \mathrm{ml}$ ). These experiments were performed in triplicate and representative figures are shown. c Quiescent BMhTERT cells plated in 96-well plates were stimulated to grow with VEGF in the presence or absence of catalase (Cat) or SOD for $48 \mathrm{~h}$. Fold increase in cell number over cells at day zero is shown. BMhTERT cells were transfected with PRDXIV cDNA and cellular proliferation was measured after 24 or 48 h of transfection. ylation of the VEGFR-1 was inhibited by resveratrol indicating that intracellular $\mathrm{O}_{2}^{-}$species also play a critical role (fig. 3a).

Then, we asked whether PlGF stimulates intracellular ROS levels. Endothelial cells were treated with PlGF in the presence or absence of extracellular SOD. Figure $3 \mathrm{~b}$ shows a significant increase in intracellular ROS in
BMhTERT that was inhibited by extracellular SOD. Since PlGF treatment led to increased levels of intracellular ROS, we hypothesize that an intracellular scavenger of ROS should downregulate the phosphorylation of MAP kinase activation. Indeed, both PlGF- and VEGF-induced phosphorylation of p44/42 MAP kinase in these cells was inhibited by resveratrol (fig. 3c, d). 


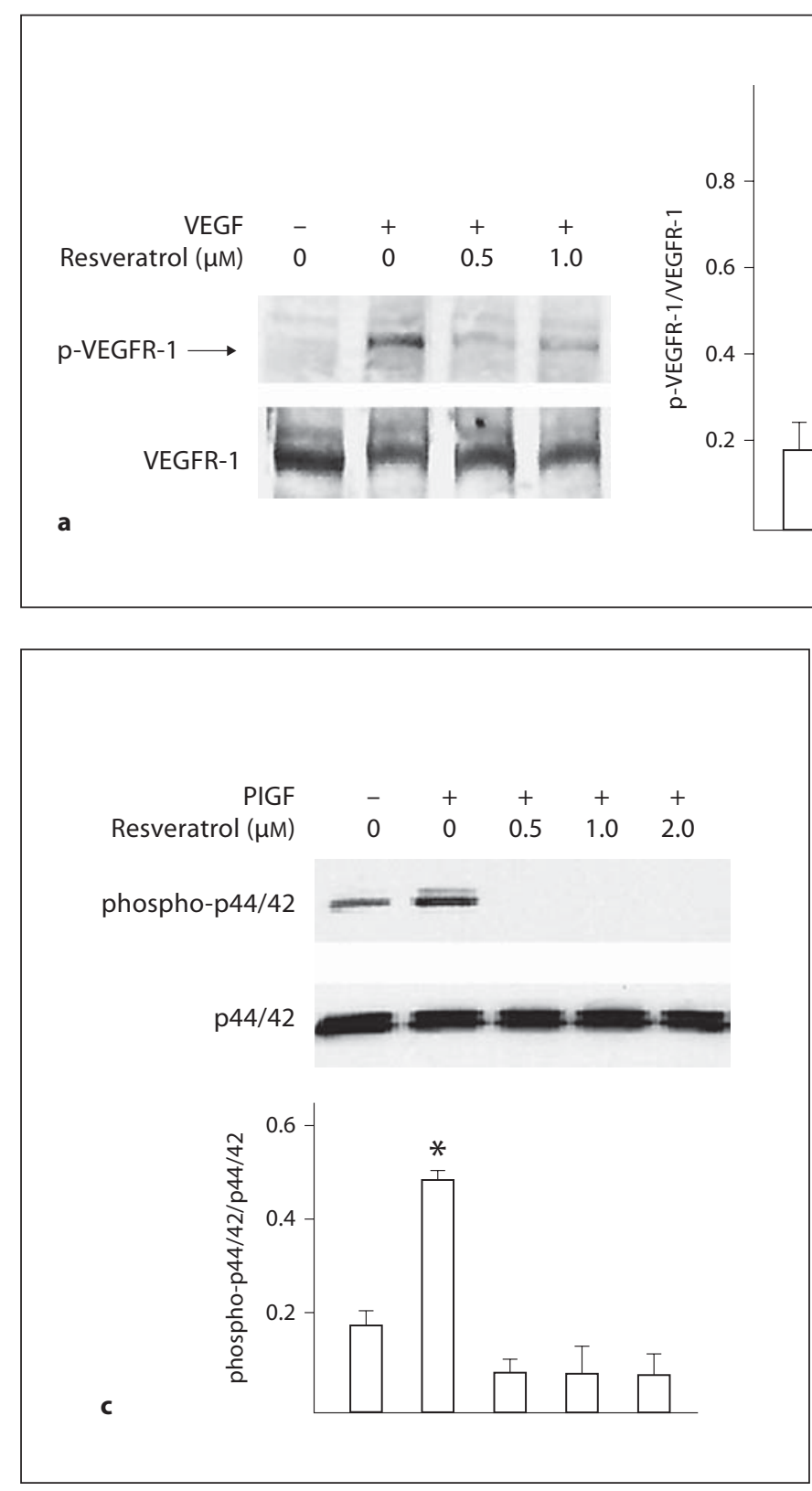

Fig. 3. VEGFR-1 phosphorylation is inhibited by intracellular superoxide scavengers. ${ }^{*} \mathrm{p}<0.05$ indicates statistical significance, using one-way ANOVA followed by Bonferroni's multiple comparison test. a BMhTERT cells were treated with indicated amounts of resveratrol followed by stimulation with VEGF for $3 \mathrm{~min}$. The histogram represents the values of the ratio between the phosphorylated protein and the total protein. $\mathbf{b}$ PlGF-induced ROS generation in BMhTERT cells. DCF fluorescence was measured $1 \mathrm{~min}$ after PlGF addition. The percent increase in cell fluorescence compared with cells not treated with the growth factor is shown. Data represent the mean from 3 experiments; each
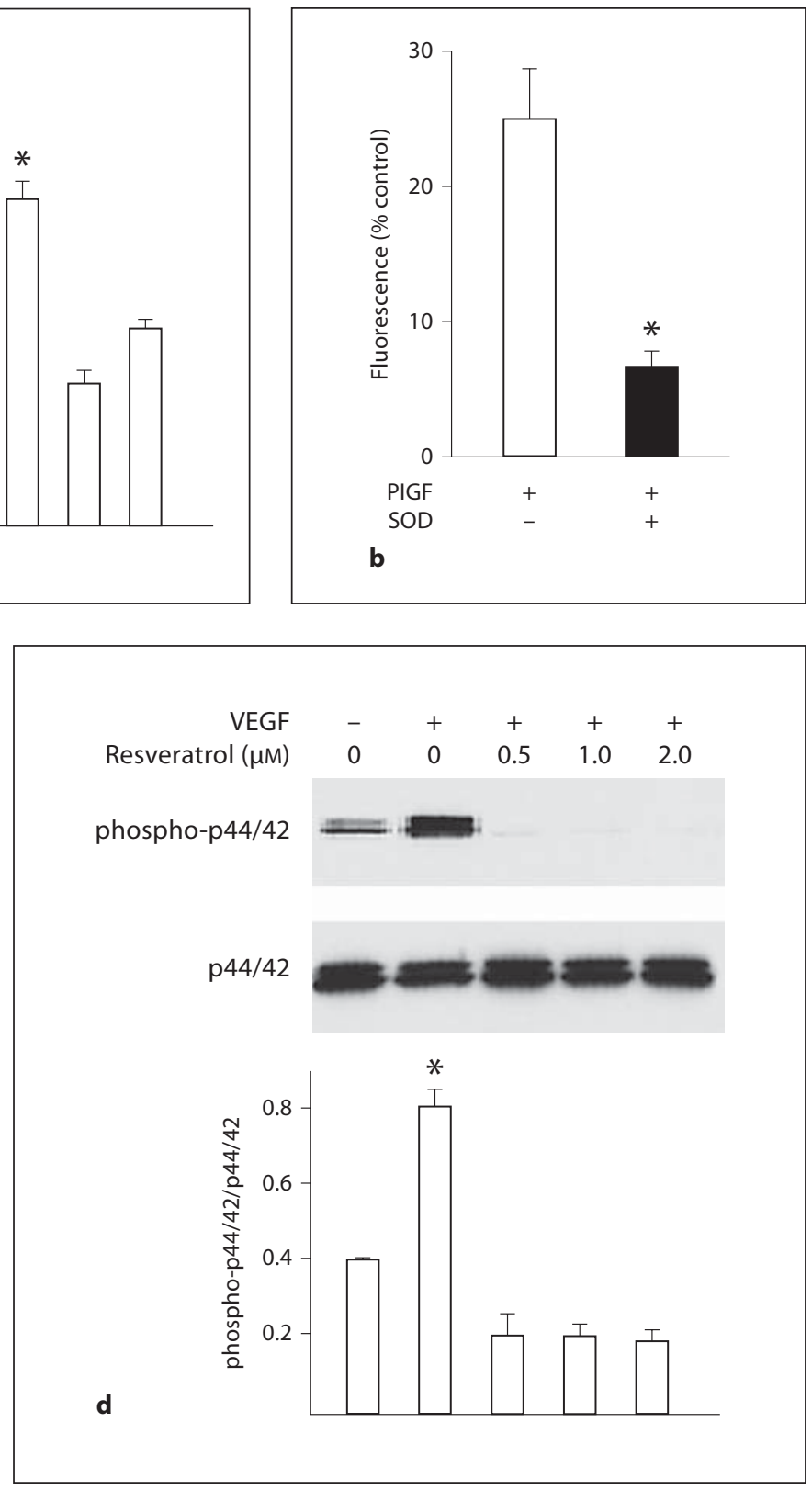

condition was in quadruplicate. c BMhTERT cells were treated with cell-permeable resveratrol, 1 or $5 \mu \mathrm{M}$, before the addition of PlGF. Western blot analysis was done for phosphorylated p42/ p44. Loading of the proteins as determined, using anti-p44/42 antibody on a duplicate blot. $\mathbf{d}$ BMhTERT cells were treated with cell permeable 1 or $5 \mu \mathrm{M}$ resveratrol, before the addition of VEGF. Western blot analysis was done for phosphorylated AKT. Loading of the proteins as determined, using anti-p44/42 antibody on a duplicate blot. The histogram represents the values of the ratio between the phosphorylated protein and the total protein. 


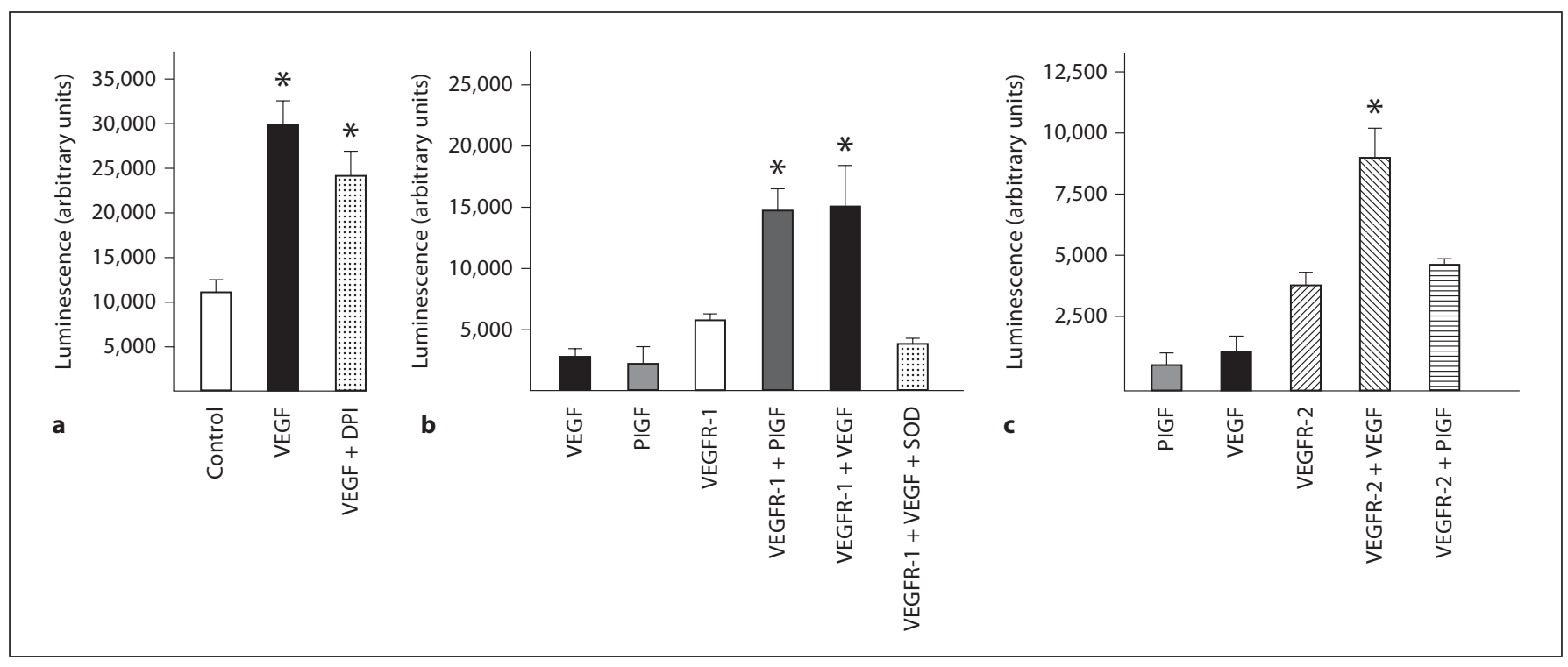

Fig. 4. Generation of superoxide upon receptor-ligand interactions. ${ }^{*} \mathrm{p}<0.05$ indicates statistical significance, using one-way ANOVA followed by Bonferroni's multiple comparison test. a Equal number of A431 cells were treated with $20 \mathrm{ng} / \mathrm{ml}$ VEGF or albumin $50 \mathrm{ng} / \mathrm{ml}$. DPI $(100 \mu \mathrm{M})$ was added $5 \mathrm{~min}$ before addition of the ligand. The histogram indicates $\mathrm{O}_{2}^{-}$production over 1 min measured by luminescence emission upon incubation with

\section{Detection of Extracellular $\mathrm{O}_{2}^{-}$}

Having demonstrated that extracellular $\mathrm{O}_{2}^{-}$was essential for VEGFR-1 and VEGFR-2 signaling, we investigated whether extracellular $\mathrm{O}_{2}^{-}$was a consequence of ligand addition to the cells. While VEGFR is expressed in endothelial cells, expression of VEGFR-2 is also upregulated in A431 cells [19]. To detect the generation of extracellular $\mathrm{O}_{2}^{-}$upon ligand-receptor interaction, A431 cells were incubated with VEGF or albumin as control (see Material and Methods). We observed $\mathrm{O}_{2}^{-}$generation seconds after addition of the ligand (fig. 4a). To rule out the contribution of NADPH membrane oxidase in the generation of $\mathrm{O}_{2}^{-}$, A431 cells were pretreated with diphenyleneiodonium (DPI; $100 \mu \mathrm{M})$, an inhibitor of NADPH oxidase. Treatment with DPI had no significant influence on the ligand-dependent generation of $\mathrm{O}_{2}^{-}$(fig. 4a). Our results rule out the contribution of membrane NADPH oxidase in the generation of $\mathrm{O}_{2}^{-}$measured and raise the possibility that receptor-ligand interaction alone is sufficient to initiate the formation of $\mathrm{O}_{2}^{-}$species. In order to further establish that VEGF and PlGF generate $\mathrm{O}_{2}^{-}$, we used a cellfree system where recombinant extracellular VEGFR1-Fc chimera was incubated with recombinant VEGF or PlGF and the superoxide generation measured with Superlu-
Superluminol. b VEGF, PlGF, VEGFR-1 and VEGFR-1 with VEGF or PlGF, VEGFR-1 and VEGF with SOD in the presence of superlumiol luciferase activity measured for $5 \mathrm{~s}$ is shown. c VEGF, PlGF, VEGFR-2 alone or VEGFR-2 with VEGF or PlGF luciferase activity measured for $5 \mathrm{~s}$ is shown. These experiments were performed twice in triplicate. The histograms represent the measurement of luminescence.

minol. PlGF and VEGF binding to VEGFR-1 triggered the production of $\mathrm{O}_{2}^{-}$(fig. $4 \mathrm{~b}$ ), and the species measured is indeed superoxide since treatment with SOD abrogates the increase. However, VEGFR-2 generated $\mathrm{O}_{2}^{-}$only when combined with VEGF but not with PlGF (fig. 4c). These results confirmed that specific ligand-receptor interaction is critical for the generation of $\mathrm{O}_{2}^{-}$.

\section{Discussion}

In this study, we addressed the role of extracellular $\mathrm{O}_{2}^{-}$during VEGF- or PlGF-mediated receptor activation. The cellular response(s) to each species of ROS appear to be tightly regulated. For instance, $\mathrm{O}_{2}^{-}$production by $\mathrm{NADPH}$ oxidase is critical for the feed forward mechanism of signaling involving c-Src activation leading to sustained oxidase activation [20]. $\mathrm{ROS}$ as $\mathrm{O}_{2}^{-}$has been implicated in endothelin-1-induced venous contraction, whereas $\mathrm{ROS}$ as $\mathrm{H}_{2} \mathrm{O}_{2}$ does not contribute to the same [21]. Induction of hypoxia-inducible factor $1 \alpha$ gene by VEGF is mediated primarily by the superoxide species [22]. Additionally, angiopoietin-induced angiogenesis is known to be dependent on superoxide from NADPH 
[23]. Similarly, low-density lipoprotein-induced VEGF and VEGFR overexpression was prevented by vitamin C, suggesting a role of intracellular superoxide in the process [24]. Therefore, the role of the $\mathrm{O}_{2}^{-}$species is emerging as necessary for maintaining several cellular processes.

Our work demonstrates that extracellular $\mathrm{O}_{2}^{-}$generated by VEGF and PlGF is sufficient to initiate receptor phosphorylation independent of the NADPH oxidase activity. We showed that extracellular application of SOD can inhibit phosphorylation of VEGFR-1. Earlier work has shown that catalase, a scavenger of $\mathrm{H}_{2} \mathrm{O}_{2}$, inhibits VEGFR-1 phosphorylation, and the source of the peroxide can be intracellular as peroxide is cell permeable, or it can be a dismutation product of $\mathrm{O}_{2}^{-}$species generated upon receptor-ligand interaction [13]. It has also been shown that NADPH oxidase activity is not required for early phosphorylation of VEGFR-2/KDR by VEGF but may play a role in maintaining the receptor in the phosphorylated state [20]. DPI, an inhibitor of flavin-containing oxidases [25], has been frequently used to block NADPH oxidase activity. In this work, we show that superoxide burst is produced in A431 cells upon VEGF treatment even in the presence of DPI, further supporting earlier observations that superoxide formation is not dependent on NADPH activity [26]. $\mathrm{O}_{2}^{-}$species which are present extracellularly have the potential to contribute to the cell-permeable $\mathrm{H}_{2} \mathrm{O}_{2}$ species which can modulate the activity of intracellular protein tyrosine phosphatases $[27,28]$, thus modulating the phosphorylation of the receptor.

The role of PlGF in angiogenesis and endothelial cell biology is less known. We show here that PIGF treatment induces intracellular ROS and that the increased ROS was dependent on extracellular $\mathrm{O}_{2}^{-}$. Squelching of intracellular hydroxyl and or $\mathrm{O}_{2}^{-}$species by resveratrol inhibited the phosphorylation of p44 MAP kinase induced by PlGF in endothelial cells.

It can be speculated that superoxide may modify the lipid microdomain of the receptor that makes intracellular kinase activation permissive and initiate the assembly of a signaling complex by modification of the adaptor molecules. Recent reports show that VEGFR-2 is localized within caveolae/lipid rafts in the basal state [29]. Caveolin-1 binds to VEGFR-2 and negatively regulates receptor activity, and VEGF stimulates tyrosine phosphorylation of caveolin.

Taken together, our study provides evidence suggesting a significant role of extracellular $\mathrm{O}_{2}^{-}$in mediating and initiating intracellular signaling due to PlGF/VEGFR-1 interaction, perhaps enhancing the established role of intracellular superoxide during ligand-receptor signaling. More important, this study revealed a new therapeutic target where an antioxidant might be sufficient to inhibit tumor cellular proliferation especially by inhibiting tumor vasculature.

\section{Acknowledgements}

We thank Dr. Lea Cleason Walsh for VEGFR-1 and VEGFR-2 cDNA and Alicia Pedraza for her technical help. The BMhTERT cell line was kindly provided by Dr. Malcolm Moore. This work was supported by grants from the National Institute of Health (CA30388) and the Lebensfeld and Shultz Foundation.

\section{References}

1 Cross MJ, Dixelius J, Matsumoto T, Claesson-Welsh L: VEGF-receptor signal transduction. Trends Biochem Sci 2003;28:488494.

-2 Terman BI, Dougher-Vermazen M, Carrion ME, Dimitrov D, Armellino DC, Gospodarowicz D, Bohlen P: Identification of the KDR tyrosine kinase as a receptor for vascular endothelial cell growth factor. Biochem Biophys Res Commun 1992;187:1579-1586.

3 Hatva E, Kaipainen A, Mentula P, Jaaskelainen J, Paetau A, Haltia M, Alitalo K: Expression of endothelial cell-specific receptor tyrosine kinases and growth factors in human brain tumors. Am J Pathol 1995;146: 368-378.
-4 Rakic JM, Lambert V, Devy L, Luttun A, Carmeliet P, Claes C, Nguyen L, Foidart JM, Noel A, Munaut C: Placental growth factor, a member of the VEGF family, contributes to the development of choroidal neovascularization. Invest Ophthalmol Vis Sci 2003;44: 3186-3193.

5 Natarajan V, Scribner WM, al-Hassani M, Vepa S: Reactive oxygen species signaling through regulation of protein tyrosine phosphorylation in endothelial cells. Environ Health Perspect 1998;106(suppl 5):12051212 .
-6 Biswas S, Gupta MK, Chattopadhyay D, Mukhopadhyay CK: Insulin-induced activation of hypoxia-inducible factor-1 requires generation of reactive oxygen species by NADPH oxidase. Am J Physiol Heart Circ Physiol 2007;292:H758-H766.

7 Bae YS, Kang SW, Seo MS, Baines IC, Tekle E, Chock PB, Rhee SG: Epidermal growth factor (EGF)-induced generation of hydrogen peroxide. Role in EGF receptor-mediated tyrosine phosphorylation. J Biol Chem 1997;272:217-221.

$>8$ Sattler M, Winkler T, Verma S, Byrne CH, Shrikhande G, Salgia R, Griffin JD: Hematopoietic growth factors signal through the formation of reactive oxygen species. Blood 1999;93:2928-2935. 
$\checkmark 9$ Blanchetot C, Boonstra J: The ROS-NOX connection in cancer and angiogenesis. Crit Rev Eukaryot Gene Expr 2008;18:35-45.

-10 Gorlach A, Brandes RP, Nguyen K, Amidi M, Dehghani F, Busse R: A gp9lphox containing NADPH oxidase selectively expressed in endothelial cells is a major source of oxygen radical generation in the arterial wall. Circ Res 2000;87:26-32.

-11 Dhar-Mascareno M, Chen J, Zhang RH, Carcamo JM, Golde DW: Granulocyte-macrophage colony-stimulating factor signals for increased glucose transport via phosphatidylinositol 3-kinase- and hydrogen peroxide-dependent mechanisms. J Biol Chem 2003;278:11107-11114.

-12 DeYulia GJ Jr, Carcamo JM, Borquez-Ojeda O, Shelton CC, Golde DW: Hydrogen peroxide generated extracellularly by receptor-ligand interaction facilitates cell signaling. Proc Natl Acad Sci USA 2005;102:50445049.

-13 Colavitti R, Pani G, Bedogni B, Anzevino R, Borrello S, Waltenberger J, Galeotti T: Reactive oxygen species as downstream mediators of angiogenic signaling by vascular endothelial growth factor receptor-2/KDR. J Biol Chem 2002;277:3101-3108.

-14 Muro S, Gajewski C, Koval M, Muzykantov VR: ICAM-1 recycling in endothelial cells: a novel pathway for sustained intracellular delivery and prolonged effects of drugs. Blood 2005; 105:650-658.

-15 MacKenzie KL, Franco S, Naiyer AJ, May C, Sadelain M, Rafii S, Moore MA: Multiple stages of malignant transformation of human endothelial cells modelled by co-expression of telomerase reverse transcriptase, SV40 T antigen and oncogenic N-ras. Oncogene 2002;21:4200-4211
16 Mayo LD, Kessler KM, Pincheira R, Warren RS, Donner DB: Vascular endothelial cell growth factor activates CRE-binding protein by signaling through the KDR receptor tyrosine kinase. J Biol Chem 2001;276: 25184-25189.

$\checkmark 17$ Lin MT, Yen ML, Lin CY, Kuo ML: Inhibition of vascular endothelial growth factorinduced angiogenesis by resveratrol through interruption of Src-dependent vascular endothelial cadherin tyrosine phosphorylation. Mol Pharmacol 2003;64:1029-1036.

18 Ashino H, Shimamura M, Nakajima H, Dombou M, Kawanaka S, Oikawa T, Iwaguchi T, Kawashima S: Novel function of ascorbic acid as an angiostatic factor. Angiogenesis 2003;6:259-269.

19 Li S, Peck-Radosavljevic M, Koller E, Koller F, Kaserer K, Kreil A, Kapiotis S, Hamwi A, Weich HA, Valent P, Angelberger P, Dudczak R, Virgolini I: Characterization of (123)I-vascular endothelial growth factorbinding sites expressed on human tumour cells: possible implication for tumour scintigraphy. Int J Cancer 2001;91:789-796.

20 Abid MR, Spokes KC, Shih SC, Aird WC: NADPH oxidase activity selectively modulates vascular endothelial growth factor signaling pathways. J Biol Chem 2007;282: 35373-35385.

21 Thakali K, Demel SL, Fink GD, Watts SW: Endothelin-1 (ET-1)-induced contraction in veins is independent of hydrogen peroxide $\left(\mathrm{H}_{2} \mathrm{O}_{2}\right)$. Am J Physiol Heart Circ Physiol 2005;289:H1115-H1122.

-22 Ushio-Fukai M, Tang Y, Fukai T, Dikalov SI, Ma Y, Fujimoto M, Quinn MT, Pagano PJ, Johnson C, Alexander RW: Novel role of gp91(phox)-containing $\mathrm{NAD}(\mathrm{P}) \mathrm{H}$ oxidase in vascular endothelial growth factor-induced signaling and angiogenesis. Circ Res 2002;91:1160-1167.
23 Chen JX, Zeng H, Lawrence ML, Blackwell TS, Meyrick B: Angiopoietin-1-induced angiogenesis is modulated by endothelial NADPH oxidase. Am J Physiol Heart Circ Physiol 2006;291:H1563-H1572.

-24 Rodriguez JA, Nespereira B, Perez-Ilzarbe M, Eguinoa E, Paramo JA: Vitamins $C$ and $E$ prevent endothelial VEGF and VEGFR-2 overexpression induced by porcine hypercholesterolemic LDL. Cardiovasc Res 2005; 65:665-673.

-25 De Minicis S, Brenner DA: NOX in liver fibrosis. Arch Biochem Biophys 2007;462: 266-272.

-26 Morazzani M, de Carvalho DD, Kovacic H, Smida-Rezgui S, Briand C, Penel C: Monolayer versus aggregate balance in survival process for EGF-induced apoptosis in A431 carcinoma cells: implication of ROS-p38 MAPK-integrin alpha2beta1 pathway. Int J Cancer 2004;110:788-799.

27 DeYulia GJ Jr, Carcamo JM: EGF receptorligand interaction generates extracellular hydrogen peroxide that inhibits EGFR-associated protein tyrosine phosphatases. Biochem Biophys Res Commun 2005;334:3842.

28 Juarez JC, Manuia M, Burnett ME, Betancourt O, Boivin B, Shaw DE, Tonks NK, Mazar AP, Donate F: Superoxide dismutase 1 (SOD1) is essential for $\mathrm{H}_{2} \mathrm{O}_{2}$-mediated oxidation and inactivation of phosphatases in growth factor signaling. Proc Natl Acad Sci USA 2008;105:7147-7152.

-29 Labrecque L, Royal I, Surprenant DS, Patterson C, Gingras D, Beliveau R: Regulation of vascular endothelial growth factor receptor2 activity by caveolin-1 and plasma membrane cholesterol. Mol Biol Cell 2003;14: 334-347. 